\title{
A Case Study of Talent Training Scheme for English Major in Local Normal University in China: Also on Necessity of offering Business English Course
}

\author{
GAO Xia HE Ji-fei \\ Chuxiong Normal University, Chuxiong, China
}

\begin{abstract}
Business English Course helps students develop international business theory ability for English majors, which can lay a good foundation for their future employment. "Normal" English curriculum is abundant in current talent training scheme for English Major of local Normal Universities. But some "non-normal" English Curriculum (such as business English) is set up seldom, which is unfavorable to the cultivation of the talents who adapt to today's society. By using the questionnaire survey provided to the teachers and students from Chuxiong Normal University, this paper analyzes the rationality and irrationality of the current talent training scheme for English Major. It puts forward some concrete measures to solve the existing problems. At the same time, the paper also analyzes the necessity and importance of cultivating English students' ability to offer Business English, and how to construct the curriculum.
\end{abstract}

Keywords -English talent training scheme, Survey report, Analysis and study, English Major, Business English course

\section{INTRODUCTION}

1.1. Talent Training Scheme for English Major

There are clear goals for English Major, which trains the English talents. The training goals for English Majors make them grasp the basic theory and professional knowledge in the field of English language and literature, and develop stronger practice ability and innovation ability. They should be able to teach English language and literature as educators. At the same time, they should be the high-quality talents who can be engaged in English translation, secretarial field, cultural exchanges and relevant work in foreign affairs, trade, and tourism and technology enterprises.

1.2. Business English Course

The purpose of Business English is adapting to the working life of language requirements, which involves all aspects of the business. Business English course not only improves student's English level and ability, but also teaches students a western concept of enterprise management and work psychology. It is even about how to deal with foreigners, how

to cooperate with them, as well as their living habits. To a certain extent, it is included in the concept of culture.

\section{ANALYSIS OF THE TALENT TRAINING SCHEME}

2.1. Rationalities of the Existing Scheme

2.1.1 Training Objectives

There are clear training goals for English Major. It trains the talents who are developed with the comprehensive development of morality, intelligence, sport, and beauty. They have the basic theory and professional knowledge in the field of English language and literature, and have strong practice ability and innovation ability. They should be able to teach and research English language and literature in middle school as educators. At the same time, they should be the high-quality talents who can be engaged in English translation, secretarial field, cultural exchanges and relevant work in foreign affairs, trade and tourism, technology enterprises.

2.1.2 Training Specifications

2.1.2.1. Quality Structures

There are good quality structures for students of English Major. The talent training scheme of English Major requires students to have a good ideological and moral quality, scientific and cultural quality, professional quality and mental quality. Among them, the scheme requires students to have the following scientific and cultural quality: based on mastering the professional knowledge, they should have a broad understanding for other social science knowledge and natural science knowledge, balancing the humanistic quality and scientific quality; a wide cultural field of vision; a certain cultural accomplishment and practice literacy; good intercultural awareness and intercultural communicative art.

2.1.2.2. Ability Structures 
There are good ability structures of acquiring knowledge, knowledge application ability and practice ability for English Major. It requires students have the independent learning ability, self-development ability, oral expression and written expression ability. In addition to, they are required to have the ability of knowledge application: teaching design ability, teaching ability, oral expression ability and learning guidance ability, organization coordinated ability.

\subsubsection{Knowledge Structures}

There are all kinds of knowledge structures for English Majors. They should have good tools knowledge, knowledge of Humanities and social science, natural science knowledge and professional technical knowledge.

\subsubsection{Main Courses}

To achieve the required training objectives and specifications in the talent training scheme for English Major, it has set up the following courses: English Reading, Spoken English, English Pronunciation, English Writing, the Second Foreign Language, Translation, Basic English, Basic English Listening, Advanced English Listening, Intermediate, and Advanced English Literature, Linguistics, Pedagogy, Psychology etc. These courses involved relevant English requirements of listening, speaking, reading, writing and translation, which enhance students' ability from junior to senior gradually.

2.2 Inadequacies of the Existing Scheme

The talent training scheme of English Major takes into account all kinds of aspects of students of English Majors. There are many reasonable and worth places in the scheme. But with the passage of time and the mature of conditions gradually, the talent training scheme still exist in some areas that can be improved. They are shown as following aspects:

\subsubsection{Aspect of Training Objectives}

The cultivation aim of the talent training scheme of English Major is developing the high-quality talents with the comprehensive development of moral, intellectual, physical, aesthetic. But the main offered courses mostly are around the literary knowledge and intellectual education courses. There is no obvious embodiment of comprehensive development.

Besides, the scheme requires students to be engaged in English-Chinese translation, secretary, cultural exchange in foreign affairs, technology trade, business and other areas. But in addition to related tourism culture in English, international trade and business and hotel English are opened as elective courses, other related courses have not been set up in English Major.

\section{2.2 Aspect of Ability}

Talent training scheme of English Major requires students to have strong practice and innovation ability. But the training platform is rarely provided for students to practice and improve innovation ability in the main courses.

What's more, the ability structure of the scheme requires students to have following ability structures. They must have good oral and written expression ability. But the related spoken and written language courses are not satisfied to these needs.

\subsubsection{Aspect of Scientific and Cultural Quality}

The talent training scheme of English Major requires students to have the following scientific and cultural quality. In addition to master the professional knowledge, students should also master the knowledge of social science, intercultural awareness and intercultural communicative art, and have good ability to adapt to society. However, the related opened courses of English major are not meet the training.

\subsubsection{Aspect of Knowledge Structure}

The knowledge structure of the talent training scheme of English Major requires students to have following knowledge structures. They must master the foreign language knowledge, and then use the knowledge acquiring new knowledge. But these practice platforms are not enough.

2.3 Measures for the Inadequacies

For the inadequacies in the talent training scheme of English Major, this study proposes the following measures:

\subsection{Aspect of Training Objectives}

In addition to continue to offer related literary knowledge and intellectual education courses, related economic and trade courses also should be opened. Business English is a good choice. Business English courses not only can increase the students' knowledge, but also can enhance students' learning on the economic and cultural, so as to further improve the comprehensive quality. Besides, only opening the main courses about technology trade and enterprise, we can effectively improve the ability in this area. Business English involves knowledge of these aspects, which can effectively meet the practical knowledge.

2.3.2 Aspect of Ability

Many courses can better train students' practice and innovation ability in the main courses. Among them, Business English is a good choice. Students can not only practice in English environment, but also can combine with the economic and cultural practice, so as to better cultivate innovation capability. What's more, Business 
English not only contains business oral communication, but also includes the business writing, which is a great help to improve students' oral and written expression ability. Thus, setting up Business English course is a good choice.

2.3.3 Aspect of Scientific and Cultural Quality

International Business English involves the aspects of economic and cultural knowledge, which laid a solid foundation for strengthening cultural exchanges between countries. At the same time, it also can strengthen the student's intercultural communicative competence and ability of social adaptation. Therefore, Business English course is a helpful course.

2.3.4. Aspect of Knowledge Structure

Business English itself belongs to the category of English. Business English courses can intensive students' English language learning. At the same time, students can use the knowledge of English to learn related economic and trade knowledge better.

3.1 Questionnaire Survey for Students

\section{ANALYSIS OF QUESTIONNAIRE SURVEY}

3.1.1 Analysis of Survey Data for 2009 English Major (Grade 4)

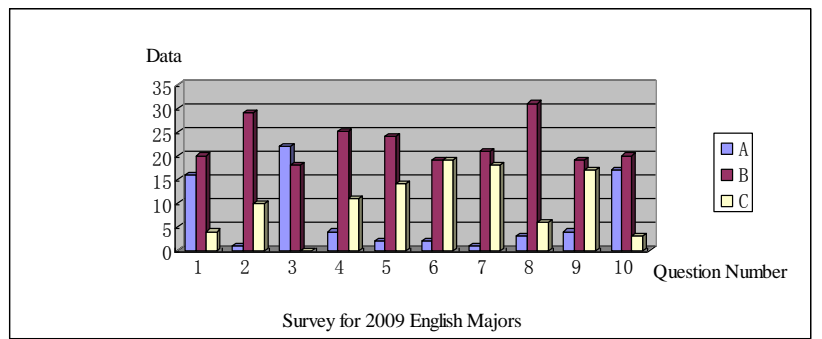

Figure 1: Analysis of Survey Data for 2009 English Major (Grade 4)

Note: the question number refers to the 1 to 10 questions in the questionnaire survey; $\mathrm{A}, \mathrm{B}, \mathrm{C}$ respectively is three different options for each question; the data refers to the number of each option (referring to Table 1).

\begin{tabular}{|c|c|c|c|c|c|c|c|c|}
\hline \multicolumn{9}{|c|}{ Table 1: Survey for 2009 English Majors(Grade 4) } \\
\hline \multirow{3}{*}{$\begin{array}{l}\text { quest } \\
\text { ion } \\
\text { num } \\
\text { ber }\end{array}$} & \multirow{3}{*}{ questions and options } & \multirow{3}{*}{$\begin{array}{l}\text { Overa } \\
11 \\
\text { numb } \\
\text { er of } \\
\text { peopl } \\
\text { e }\end{array}$} & \multicolumn{6}{|c|}{ Answers } \\
\hline & & & \multicolumn{2}{|c|}{ A } & \multicolumn{2}{|c|}{ B } & \multicolumn{2}{|c|}{$\mathrm{C}$} \\
\hline & & & $\begin{array}{c}\text { num } \\
\text { ber } \\
\text { of } \\
\text { peop } \\
\text { le }\end{array}$ & $\begin{array}{l}\text { Proport } \\
\text { ion }(\%)\end{array}$ & $\begin{array}{c}\text { num } \\
\text { ber } \\
\text { of } \\
\text { peop } \\
\text { le }\end{array}$ & $\begin{array}{l}\text { Proport } \\
\text { ion }(\%)\end{array}$ & $\begin{array}{c}\text { num } \\
\text { ber } \\
\text { of } \\
\text { peop } \\
\text { le }\end{array}$ & $\begin{array}{l}\text { Proport } \\
\text { ion }(\%)\end{array}$ \\
\hline 1 & $\begin{array}{l}\text { Do you know the training } \\
\text { objectives of English Major of } \\
\text { Foreign Language Department } \\
\text { of Chuxiong Normal } \\
\text { University? (A. clear B. not too } \\
\text { clear C. do not know) }\end{array}$ & 40 & 24 & 60 & 15 & 37.5 & 1 & 2.5 \\
\hline 2 & $\begin{array}{l}\text { Do you know the training } \\
\text { specifications of English Major } \\
\text { of Foreign Language } \\
\text { Department of Chuxiong } \\
\text { Normal University? (A. clear B. } \\
\text { not too clear C. do not know) }\end{array}$ & 40 & 9 & 22.5 & 26 & 65 & 5 & 12.5 \\
\hline 3 & $\begin{array}{l}\text { Do you know the course } \\
\text { classification of English Major } \\
\text { of Foreign Language } \\
\text { Department of Chuxiong } \\
\text { Normal University? (A. clear B. } \\
\text { not too clear C. do not know) }\end{array}$ & 40 & 33 & 82.5 & 7 & 17.5 & 0 & 0 \\
\hline
\end{tabular}




\begin{tabular}{|c|c|c|c|c|c|c|c|c|}
\hline 4 & $\begin{array}{l}\text { Are you satisfied with the } \\
\text { categories of major for English } \\
\text { Major of Foreign Language } \\
\text { Department of Chuxiong } \\
\text { Normal University? ( A. } \\
\text { satisfied B. not too satisfied } \\
\text { C. unsatisfied) }\end{array}$ & 40 & 4 & 10 & 31 & 77.5 & 5 & 12.5 \\
\hline 5 & $\begin{array}{l}\text { Did you know of related } \\
\text { knowledge about Business } \\
\text { English? (A. deep understand } \\
\text { B. a little understand C. no } \\
\text { understand) }\end{array}$ & 40 & 1 & 2.5 & 29 & 72.5 & 10 & 25 \\
\hline 6 & $\begin{array}{l}\text { Have you read some related } \\
\text { books on Business English with } \\
\text { your spare time? (A. very much } \\
\begin{array}{ll}\text { B. a litter } & \text { C. no) }\end{array}\end{array}$ & 40 & 2 & 5 & 27 & 67.5 & 11 & 27.5 \\
\hline 7 & $\begin{array}{l}\text { Have you known of the } \\
\text { situation and prospects of } \\
\text { business English? (A. deep } \\
\text { understand } \\
\text { understand C. no understand ) }\end{array}$ & 40 & 0 & 0 & 33 & 82.5 & 7 & 17.5 \\
\hline 8 & $\begin{array}{l}\text { Are there students who want to } \\
\text { learn Business English or are } \\
\text { learning it around you? ( A. } \\
\text { very much B.several } \\
\text { none) }\end{array}$ & 40 & 3 & 7.5 & 24 & 60 & 13 & 32.5 \\
\hline 9 & $\begin{array}{l}\text { Have ever teachers encouraged } \\
\text { the students to use their spare } \\
\text { time to study e-commerce? (A. } \\
\text { very much } \quad \text { B. several C. } \\
\text { none) }\end{array}$ & 40 & 1 & 2.5 & 28 & 70 & 11 & 27.5 \\
\hline 10 & $\begin{array}{l}\text { Do you hope to set up the } \\
\text { Business English course in } \\
\text { English Major of Foreign } \\
\text { Language Department of } \\
\text { Chuxiong Normal University? } \\
\text { (A. quite B. a litter C. do not) }\end{array}$ & 40 & 22 & 55 & 18 & 45 & 0 & 0 \\
\hline
\end{tabular}

The questionnaire issued in English Majors of 2009 (Grade 4) is 42, and the final recovery is 40. As shown in the above, so the rate of efficiency is $95 \%$.

3.1.2 Analysis of Survey Data for 2010 English Major (Grade 3)

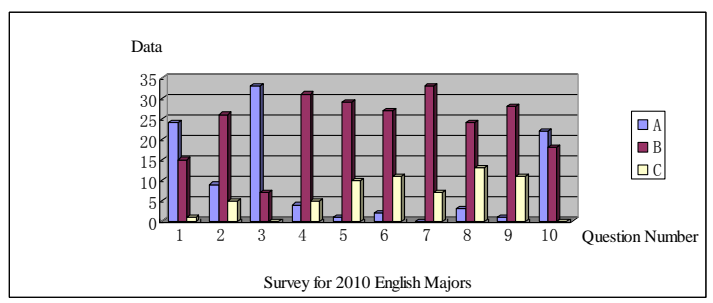

Figure 2: Analysis of Survey Data for 2010 English Major (Grade 3)

Note: the question number refers to the 1 to 10 questions in the questionnaire survey; $\mathrm{A}, \mathrm{B}, \mathrm{C}$ respectively is three different options for each question; the data refers to the number of each option (referring to Table 2).

\begin{tabular}{|c|c|c|c|c|c|c|c|c|}
\hline \multicolumn{9}{|c|}{ Table 2: Survey for 2010 (Grade 3)English Majors } \\
\hline \multirow{3}{*}{$\begin{array}{l}\text { quest } \\
\text { ion } \\
\text { num } \\
\text { ber }\end{array}$} & \multirow{3}{*}{ questions and options } & \multirow{3}{*}{$\begin{array}{l}\text { Overa } \\
11 \\
\text { numb } \\
\text { er of } \\
\text { peopl }\end{array}$} & \multicolumn{6}{|c|}{ Answers } \\
\hline & & & \multicolumn{2}{|c|}{$\bar{A}$} & \multicolumn{2}{|c|}{$\mathrm{B}$} & \multicolumn{2}{|c|}{$\mathrm{C}$} \\
\hline & & & $\begin{array}{c}\text { num } \\
\text { ber } \\
\text { of }\end{array}$ & $\begin{array}{l}\text { Proport } \\
\text { ion }(\%)\end{array}$ & $\begin{array}{c}\text { num } \\
\text { ber } \\
\text { of }\end{array}$ & $\begin{array}{l}\text { Proport } \\
\text { ion }(\%)\end{array}$ & $\begin{array}{c}\text { num } \\
\text { ber } \\
\text { of }\end{array}$ & $\begin{array}{l}\text { Proport } \\
\text { ion }(\%)\end{array}$ \\
\hline
\end{tabular}




\begin{tabular}{|c|c|c|c|c|c|c|c|c|}
\hline & & $\mathrm{e}$ & $\begin{array}{c}\text { peopl } \\
\mathrm{e}\end{array}$ & & $\begin{array}{c}\text { peopl } \\
\mathrm{e}\end{array}$ & & $\begin{array}{c}\text { peopl } \\
\mathrm{e}\end{array}$ & \\
\hline 1 & $\begin{array}{l}\text { Do you know the training } \\
\text { objectives of English Major of } \\
\text { Foreign Language Department } \\
\text { of Chuxiong Normal } \\
\text { University? (A. clear B. not too } \\
\text { clear C. do not know) }\end{array}$ & 40 & 24 & 60 & 15 & 37.5 & 1 & 2.5 \\
\hline 2 & $\begin{array}{l}\text { Do you know the training } \\
\text { specifications of English Major } \\
\text { of Foreign Language } \\
\text { Department of Chuxiong } \\
\text { Normal University? (A. clear B. } \\
\text { not too clear C. do not know) }\end{array}$ & 40 & 9 & 22.5 & 26 & 65 & 5 & 12.5 \\
\hline 3 & $\begin{array}{l}\text { Do you know the course } \\
\text { classification of English Major } \\
\text { of Foreign Language } \\
\text { Department of Chuxiong } \\
\text { Normal University? (A. clear B. } \\
\text { not too clear C. do not know) }\end{array}$ & 40 & 33 & 82.5 & 7 & 17.5 & 0 & 0 \\
\hline 4 & $\begin{array}{l}\text { Are you satisfied with the } \\
\text { categories of major for English } \\
\text { Major of Foreign Language } \\
\text { Department of Chuxiong } \\
\text { Normal University? ( A. } \\
\text { satisfied B. not too satisfied } \\
\text { C. unsatisfied) }\end{array}$ & 40 & 4 & 10 & 31 & 77.5 & 5 & 12.5 \\
\hline 5 & $\begin{array}{l}\text { Did you know of related } \\
\text { knowledge about Business } \\
\text { English? (A. deep understand B. } \\
\begin{array}{ll}\text { a little understand } & \text { C. no } \\
\text { understand) } & \end{array}\end{array}$ & 40 & 1 & 2.5 & 29 & 72.5 & 10 & 25 \\
\hline 6 & $\begin{array}{l}\text { Have you read some related } \\
\text { books on Business English with } \\
\text { your spare time? (A. very much } \\
\begin{array}{ll}\text { B. a litter } & \text { C. no) }\end{array}\end{array}$ & 40 & 2 & 5 & 27 & 67.5 & 11 & 27.5 \\
\hline 7 & $\begin{array}{l}\text { Have you known of the } \\
\text { situation and prospects of } \\
\text { business English? (A. deep } \\
\text { understand } \quad \text { B. a little } \\
\text { understand C. no understand ) }\end{array}$ & 40 & 0 & 0 & 33 & 82.5 & 7 & 17.5 \\
\hline 8 & $\begin{array}{l}\text { Are there students who want to } \\
\text { learn Business English or are } \\
\text { learning it around you? ( A. } \\
\text { very much B.several C. none) }\end{array}$ & 40 & 3 & 7.5 & 24 & 60 & 13 & 32.5 \\
\hline 9 & $\begin{array}{l}\text { Have ever teachers encouraged } \\
\text { the students to use their spare } \\
\text { time to study e-commerce? (A. } \\
\text { very much } \quad \text { B. several C. } \\
\text { none) }\end{array}$ & 40 & 1 & 2.5 & 28 & 70 & 11 & 27.5 \\
\hline 10 & $\begin{array}{l}\text { Do you hope to set up the } \\
\text { Business English course in } \\
\text { English Major of Foreign } \\
\text { Language Department of } \\
\text { Chuxiong Normal University? } \\
\text { (A. quite B. a litter C. do not ) }\end{array}$ & 40 & 22 & 55 & 18 & 45 & 0 & 0 \\
\hline
\end{tabular}

The questionnaire issued in 2010 English Majors (Grade 3) is 45, and the final recovery is 40. As shown in the above, so the rate of efficiency is $89 \%$. 
3.1.3 Comprehensive Analysis of Survey Data for Grade 4 and Grade 3 English Majors

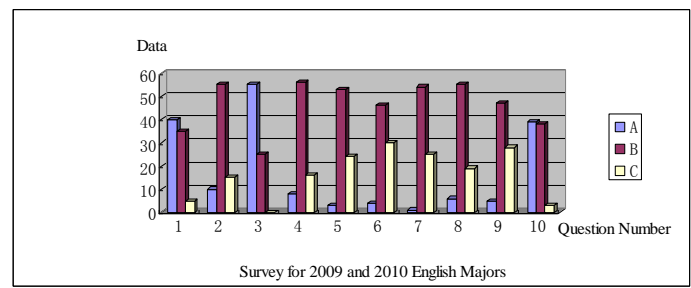

Figure 3: Survey Data for 2009 (Grade 4)and 2010(Grade 3) English Majors

Note: the question number refers to the 1 to 10 questions in the questionnaire survey; $\mathrm{A}, \mathrm{B}, \mathrm{C}$

respectively is three different options for each question; the data refers to the number of each option (referring to Table 3).

\begin{tabular}{|c|c|c|c|c|c|c|c|c|}
\hline \multirow{3}{*}{$\begin{array}{l}\text { quest } \\
\text { ion } \\
\text { num } \\
\text { ber }\end{array}$} & \multirow{3}{*}{ questions and options } & \multirow{3}{*}{$\begin{array}{l}\text { Overal } \\
1 \\
\text { numbe } \\
r \text { of } \\
\text { people }\end{array}$} & \multicolumn{6}{|c|}{ Answers } \\
\hline & & & \multicolumn{2}{|c|}{ A } & \multicolumn{2}{|c|}{ B } & \multicolumn{2}{|c|}{$\mathrm{C}$} \\
\hline & & & $\begin{array}{l}\text { numb } \\
\text { er of } \\
\text { peopl } \\
\text { e }\end{array}$ & $\begin{array}{l}\text { Proport } \\
\text { ion }(\%)\end{array}$ & $\begin{array}{l}\text { numb } \\
\text { er of } \\
\text { peopl } \\
\text { e }\end{array}$ & $\begin{array}{l}\text { Proport } \\
\text { ion }(\%)\end{array}$ & $\begin{array}{l}\text { numb } \\
\text { er of } \\
\text { peopl } \\
\text { e }\end{array}$ & $\begin{array}{l}\text { Proport } \\
\text { ion }(\%)\end{array}$ \\
\hline 1 & $\begin{array}{l}\text { Do you know the training } \\
\text { objectives of English Major of } \\
\text { Foreign Language Department of } \\
\text { Chuxiong Normal University? } \\
\text { (A. clear B. not too clear C. do } \\
\text { not know) }\end{array}$ & 80 & 40 & 50 & 35 & 43.75 & 5 & 6.25 \\
\hline 2 & $\begin{array}{l}\text { Do you know the training } \\
\text { specifications of English Major } \\
\text { of Foreign Language Department } \\
\text { of Chuxiong Normal University? } \\
\text { (A. clear B. not too clear C. do } \\
\text { not know) }\end{array}$ & 80 & 10 & 12.5 & 55 & 68.75 & 15 & 18.75 \\
\hline 3 & $\begin{array}{l}\text { Do you know the course } \\
\text { classification of English Major of } \\
\text { Foreign Language Department of } \\
\text { Chuxiong Normal University? } \\
\text { (A. clear B. not too clear C. do } \\
\text { not know) }\end{array}$ & 80 & 55 & 68.75 & 25 & 31.25 & 0 & 0 \\
\hline 4 & $\begin{array}{l}\text { Are you satisfied with the } \\
\text { categories of major for English } \\
\text { Major of Foreign Language } \\
\text { Department of Chuxiong Normal } \\
\text { University? ( A. satisfied B. not } \\
\text { too satisfied C. unsatisfied) }\end{array}$ & 80 & 8 & 10 & 56 & 70 & 16 & 20 \\
\hline 5 & $\begin{array}{l}\text { Did you know of related } \\
\text { knowledge about } \\
\text { English? (A. deep understand B. } \\
\begin{array}{ll}\text { a little understand } & \text { C. no } \\
\text { understand ) } & \end{array}\end{array}$ & 80 & 3 & 3.75 & 53 & 66.25 & 24 & 30 \\
\hline 6 & $\begin{array}{l}\text { Have you read some related } \\
\text { books on Business English with } \\
\text { your spare time? (A. very much } \\
\text { B. a litter } \quad \text { C. no) }\end{array}$ & 80 & 4 & 5 & 46 & 57.5 & 30 & 37.5 \\
\hline 7 & $\begin{array}{l}\text { Have you known of the situation } \\
\text { and prospects of business } \\
\text { English? (A. deep understand B. } \\
\begin{array}{ll}\text { a little understand } & \text { C. no } \\
\text { understand) } & \end{array}\end{array}$ & 80 & 1 & 1.25 & 54 & 67.5 & 25 & 31.25 \\
\hline
\end{tabular}




\begin{tabular}{|c|l|l|l|l|l|l|l|l|}
\hline 8 & $\begin{array}{l}\text { Are there students who want to } \\
\text { learn Business English or are } \\
\text { learning it around you? A. very } \\
\text { much B.several C. none) }\end{array}$ & 80 & 6 & 7.5 & 55 & 68.75 & 19 & 23.75 \\
\hline 9 & $\begin{array}{l}\text { Have ever teachers encouraged } \\
\text { the students to use their spare } \\
\text { time to study e-commerce? } \\
\text { very much B. }\end{array}$ & 80 & 5 & 6.25 & 47 & 58.75 & 28 & 40 \\
\hline 10 & $\begin{array}{l}\text { Do you hope to set up the } \\
\text { Business English course in } \\
\text { English Major of Foreign } \\
\text { Language Department of } \\
\text { Chuxiong Normal University? } \\
\text { (A. quite B. litter C. }\end{array}$ & & 39 & 48.75 & 38 & 47.5 & 3 & 3.75 \\
\hline
\end{tabular}

The questionnaire issued in Grade 4 and Grade 3 is 87 , and the final recovery is 80 . As shown in the above, so the rate of efficiency is $92 \%$.

3.2 Questionnaire Survey for Teachers

The questions are the following:

- Do you think whether it is necessary to set up the Business English course for English Major from Foreign Languages \& Literature?/ - How to construct the Business English?/ - Which advantages do you think do English Majors have if they set up the Business English course?

According to the interviews of English teacher, $68 \%$ of them think it is necessary to set up business English. Although English Major belongs to normal school, the main curriculums are normal education curriculum, and this kind of curriculum has been abundant. But non-normal courses (such as business English) are rarely involved. In addition, they also talk about how to establish the course and the future prospects of it.

3.3. Survey Results

According to analysis on the questionnaire survey to the students of Grade 4 or Grade 3 respectively, or to the comprehensive analysis, the conclusions are similar. They should deepen the understanding of the training objectives and specifications. They should learn some Business English before graduation. At the same time, they want to make the appropriate adjustments to the curriculum for English Major. Most of the students hope to set up business English courses. The most important result is that setting up the Business English course is necessary for English Major.

\section{NECESSITY OF SETTING UP OF BUSINESS ENGLISH COURSE}

\subsection{Environment at Home and Abroad}

First of all, Economic globalization has shown strong vitality, and has caused a great impact to all aspects of the world economy, politics, military, society, culture, even the way of thinking. What's more, there is no doubt that the world is becoming an indivisible organic whole. The most widely used language, English, played a very important role all over the world. Under the background of frequent exchanges of global business and trade activities, International Business English is playing a more and more important role.

Besides, China has formed a full range, wide field, multi-level opening-up pattern after reform and opening up of 30 years. On the one hand, changes of the external economic environment will affect the domestic economy through various channels; on the other hand, the world economy is inseparable from China. However, the implementation of all the major achievements is inseparable from a reasonable and effective exchange environment. Therefore, strengthening the construction of International Business English, creating a good international environment and achieving a good trade pattern of win-win are a great strategic decision.

Finally, the cross-border sub-regional economic cooperation zone includes Laos, Burma, Vietnam and Thailand. In the trend of economic globalization and collectivize, the development of world economy show as the regional economic development in the world. Especially after the formation of association of Southeast Asian nations, Yunnan province has become the economic partnership bridgehead of China and ASEAN (Association of Southeast Asian Nations). Therefore, seizing this rare opportunity, strengthening the construction of economy and culture, creating a good environment are benefit for various economic and trade activities carrying out smoothly. Among them, business English will play an increasingly important role.

4.2 Construction of Business English Course

China strengthened the exchanges and cooperation with other countries after the accession to the WTO. This requires us to cultivate lots of versatile talents who have no language barrier and can understand the professional knowledge. Moreover, China's higher education has changed from elite education to mass education. At the same time, China's English education has raised the general level. If it is in accordance with 
the original teaching outline, it will out of line with the market demand. From the point of view of short-term, it will affect students' employment; from the point of view of short-term, it will influence the development of English Majors in china. In recent years, the domestic researchers have studied on the reform of College English education system and teaching mode, such as QIN Xiubai (2008) , [1] LIU Runqing(2002), [2], and DAI Manchun (2004),[3]. The obvious conclusion is that English majors should cultivate high-quality composite English talents. Therefore, ESP courses are very important in the curriculum of. In other words, if English majors do not open related ESP courses during the undergraduate, it will not be able to meet the requirements of graduates. Thus, Business English teaching curriculum become the first issue to be considered.

\subsubsection{Curriculum System}

The guiding ideology of Business English curriculum system originated from the "English Teaching Syllabus for English Majors Outline “(2000).”[4] The Outline clearly pointed out that English Majors in universities should cultivate the knowledgeable talents who can engaged in translation, teaching, management, research and other work in foreign affairs, trade, culture, education, science and technology, military and other departments. In order to achieve the talent training specifications of twenty-first Century, the English courses of 4 years are divided into three modules in the "Outline", namely English skills, knowledge of English majors and related professional knowledge.

Adding Business English course in the undergraduate grade one or two (initial, intermediate) is the basis knowledge of Business English. To reflect the consistency of knowledge, English Major should continue to study advanced Business English in the fifth semester. It consolidates the Business English knowledge of the initial stage. Writing skills, especially the theme of business writing, is necessary to carry out the business activities smoothly. At the same time, taking into account the talent training scheme requiring graduates to have higher English speaking and writing skills, English Major should strengthen the training on students' writing ability. The third grade should add course of Business English Writing on the base of the second grade basic writing. This course includes not only the most content of Business English correspondence, but also covers the business contract, business proposal, specification, plan and various writing. The advanced Business English course as well as business English audio-visual proportion should be added in high grade level. It not only can develop students' comprehensive knowledge of Business English, but also can improve their business actual combat skills.

\subsubsection{Principles}

Because of the characteristic of Business English Majors, the construction of Business English curriculum system should follow the following basic principles:

- Highlight the principle of talent training positioning

Business English emerges as the needs of the society. The goal is that training the talents to meet the needs of society. So the curriculum system should be made according to the target of talent training positioning.

- Scientific principle

Any curriculum is built on the basis of science. It not only should fully reflect the needs of society, but also should follow the curriculum design rules from simple to complex, from basic to professional, from theory to practice.

- Systematic principle

The composite features of "English + business" require that curriculum should not only follow the system, but also combine with the system. It not only should pay attention to the students' comprehensive learning of theory knowledge, but also should cultivate the ability of English language skills in a business context. It embodies the continuity and the level of knowledge.

- Principle of keeping pace with the times

As long as follow the pace of the times, in the curriculum fully in line with international standards, and enable students to learn the international advanced business knowledge, it can achieve the ultimate goal of talent training.

This curriculum system will cultivate the students' solid language ability. They will not only master the business knowledge, but also improve the comprehensive ability and quality. Based on mastering solid theoretical knowledge, they can use English to successfully participate in international business activities, dealing with foreign trade business. In the process of participation in social practice, they can make full use of the knowledge of Business English Majors. They can also withstand the test of practice. There is no doubt that they will be universally praised by many companies.

\section{CONCLUSION}

Ellis and Johnson (1994) hold that Business English has its special nature of the corpus, focusing on special communicative context. [5] They also regard that Business English is actually the English used in business. That is to say, Business English is the specific English that professional talent who is engaged in or will be engaged in the business is learning. Based on the careful analysis and research of the talent training 
scheme of English Major, setting up Business English courses for English major is necessary. This is not only conformity with the requirements of the talent training scheme of English Major, but also conformity with the requirements for the students of English Major.

\section{ACKNOWLEDGEMENTS}

The research is financed by Chuxiong Normal University Key Subject Construction Project (2015, The cultivation of English language and Literature) : Cultural Translation Studies in English and Chinese.

\section{REFERENCES}

[1] QIN Xiubai, Adhering to the Humanistic Concept of Teaching and Learning and Implementing college English Curriculum Requirements in an All-round Way, Computer-Assisted Foreign Language Education, (3), 2008, 3-7.

[2] LIU Runqing, On Reform of the Syllabus of English Teaching -- from Separate Syllabus to Unified Curriculum Standard, Foreign Language Teaching and Research, (6), 2002, 403-404.

[3] LIU Runqing, DAI Manchun, On the Reform of College English Teaching in China, Teaching English in China, (4),2004,3-8.

[4] Syllabus for English Majors in Colleges and universities (revised in 2000), http://wenku.baidu.com/link?url=MpSQItc0UD8Kh5YSlzIbcjKzGWfLUrUIXQYwMI3Fq0aa0em 5H2q1QdjdfiwTK9zJCD8kkk0YvoMGv6Z8Aj4jOvsWaDPZgx9Z_vHIeiKLvI3, Nov 7,2015.

[5] Ellis M \& John C. Teaching Business English . Oxford: Oxford University Press, 1994: 3-14.

\section{AUTHOR'S BIOGRAPHY}

GAO Xia: Born in 1968 in Chuxiong, China. She received her Master degree in Teaching Chinese as A Second Language from Beijing Normal University, China in 2002. She is currently an associate professor in School of Foreign Languages \& Literature, Chuxiong Normal University, Chuxiong, China. Her research interests include the Second Language Acquisition, language and culture in English speaking countries.

HE Ji-fei: Born in 1993 in Zhaotong, China. He received his Bachelor degree in English Language \& Literature in 2012, from Chuxiong Normal University, China. He is now studying and working in Toyama-ken, Japan. 